\title{
The Effect of Torrefaction Pre-Treatment on the Gasification of Biomass
}

\author{
Manoj K. Raut ${ }^{1}$, Prabir Basu ${ }^{2}$ and Bishnu Acharya ${ }^{3}$ \\ ${ }^{1,2}$ Mechanical Engineering Department, Dalhousie University, Halifax, Canada \\ ${ }^{3}$ Greenfield Research Incorporated, Halifax, Canada \\ Correspondence should be addressed to: Bishnu Acharya; bishnu.acharya@greenfieldresearch.ca \\ Received date: 16 March 2015; Accepted date: 24 April 2015; published date: 1 September 2016 \\ Academic Editor: Jinsong Zhou \\ Copyright (C 2016. Manoj K. Raut, Prabir Basu and Bishnu Acharya. Distributed under Creative \\ Commons CC-BY 4.0
}

\begin{abstract}
Raw biomass has enormous potential as a feedstock for gasification, but its inherent characteristics limit its wide scale use. Properties such as high moisture content, high 0/C ratio, low bulk density, heterogeneous nature, and lower grindability make its handling and gasification difficult. Furthermore, higher tar formation during the gasification of raw biomass increases the downstream cost of gas separation. Pre-treatment of biomass through torrefaction could remove some of these limitations, making biomass more suitable for gasification. Experiments in both batch and continuous modes of steam-gasification show that torrefaction pre-treatment decreases the tar by $79 \%$ and increases the quality of product gas. However, reactivity and the gas yield are found to be lower for torrefied biomass than raw biomass. The effect of torrefaction and gasification temperature on the product composition showed $\mathrm{H}_{2} / \mathrm{CO}$ ratio $1.5,1.7$ and 1.9 for raw, torrefied biomass at $250^{\circ} \mathrm{C}$ and $275^{\circ} \mathrm{C}$ respectively. Scanning Electron Microscope (SEM) analysis showed less fibrous characteristics of torrefied biomass. Brunauer-Emmett-Teller (BET) analysis of raw and torrefied biomass shows higher surface area for torrefied biomass char as compared to raw biomass char after devolatilization. The results are discussed in the paper.
\end{abstract}

Keywords: Torrefaction; Gasification; Kinetics of steam gasification; Biomass energy

\section{Introduction}

Biomass is favoured as an alternative renewable fuel for heat, power and liquid fuel production (Svoboda et al. 2009). Gasification is being considered for the thermochemical conversion of biomass to produce clean and quality heat, power and liquid fuels from biomass (Bhagavatula 2014). It could facilitate the use of biomass for co-firing in large coal-fired plant, distributed power generation using diesel

Cite this Article as: Manoj K. Raut, Prabir Basu and Bishnu Acharya (2016)," The Effect of Torrefaction Pre-Treatment on the Gasification of Biomass " International Journal of Renewable Energy and Biofuels, Vol. 2016 (2016), Article ID 823723, DOI: 10.5171/2016.823723 
engine, production of chemical fuels and even clean cooking in houses or communities (Meijden et al. 2012; Bhagavatula 2014)). However, some inherent properties of biomass like high moisture content, low bulk density and heating value, fibrous nature, hydroscopic nature, bio-degradability, difficulty in grinding makes its use very difficult. Additionally, tar produced during gasification is a major challenge that hinders its downstream use (Devi et al. 2003). The attempt made to reduce the tar content either by burning like in downdraft gasifier or by using catalyst either lowers the quality of the gas or adds additional complexity to the system (Dutta and Acharya, 2010). To overcome such limitation, it is necessary to explore a pretreatment process of biomass, which could enhance biomass properties to make it favourable for gasification. Torrefaction, a mild pyrolysis process within the temperature range of $200-300^{\circ} \mathrm{C}$ in an inert environment (Basu 2013), is one such pretreatment process. It makes biomass more brittle, homogenous and hydrophobic with increased the bulk density and heating value (Bergman et al. 2004). Furthermore, it reduces $\mathrm{H} / \mathrm{C}$ and $\mathrm{O} / \mathrm{C}$ ratio of biomass to values similar to that of coal. This reduction in $\mathrm{H} / \mathrm{C}$ and $\mathrm{O} / \mathrm{C}$ ratio in fuel further helps to improve the quality of the gas produced during gasification (Prins et al. 2006). Another major advantage of torrefaction is reduction in tar released during gasification. Because of these benefits there has been much interest in torrefaction and several studies have been done to understand the process. However, the application of torrefied biomass in gasification remains largely unexplored. Fisher et al. (2012) and Couhert et al. (2009) tried to understand the kinetics of torrefied biomass char and the effect of torrefaction on the physical structure of biomass. This work examines the kinetics of steam gasification reaction for raw and torrefied biomass using a batch reactor. Steam gasification of torrefied biomass in a bubbling fluidized bed gasifier is also studied to examine the effect of torrefaction on the production gas composition and yield. The effect of torrefaction temperature on tar yield and gas yield of gasification is also studied. SEM and BET analysis is carried out to understand the change in the morphology and pore surface area of biomass during torrefaction and gasification.

\section{Material and Methods}

Table 1 shows the proximate and ultimate analysis of poplar wood chosen for the study. The proximate analysis of biomass is performed by using Benchtop Muffle Furnace (Omega Lux, LMF-3550) and Analytical Balance (Intell-Lab, PXC-200) and following ASTM D1762-84 (2007) standard for the present research. Ultimate analysis of raw and torrefied samples is performed by using an Elemental Analyzer (Thermo Quest, EA 1110) to analyse the hydrogen, carbon, nitrogen, sulfur and oxygen content. The analyzer is equipped with a gas chromatographic Porapak PQS column and auto sampler. The higher heating values of the raw and torrefied poplar wood are obtained by using Parr 6100 calorimeter.

For comparing the gasification of two feedstock (raw biomass and torrefied biomass) on a uniform base, both were devolatilized at a fixed temperature of $800^{\circ} \mathrm{C}$, and then subjected to steam gasification in batch - Quartz Wool Matrix (QWM) reactor as well as in continuous Bubbling Fluidized Bed (BFB) reactor. The quartz wool matrix reactor simulates the reaction of the solid reactant with the gaseous medium that resembles the fixed bed or the moving bed reactor. 
Table 1: Proximate and ultimate analysis of raw and torrefied poplar wood

\begin{tabular}{|c|c|c|c|c|c|c|c|c|c|c|}
\hline & \multicolumn{4}{|c|}{ Proximate Analysis (\%) } & \multicolumn{5}{|c|}{ Ultimate Analysis (\%) } & \multirow{3}{*}{$\begin{array}{l}\begin{array}{l}\text { Heating } \\
\text { Value }\end{array} \\
\text { HHV } \\
\text { (MJ } / \mathrm{kg})\end{array}$} \\
\hline & \multirow{2}{*}{$\begin{array}{l}\text { Moisture } \\
\text { Content }\end{array}$} & \multicolumn{3}{|c|}{ Dry Basis } & \multirow[b]{2}{*}{ Carbon } & \multirow[b]{2}{*}{ Hydrogen } & \multirow[b]{2}{*}{ Nitrogen } & \multirow[b]{2}{*}{ Oxygen } & \multirow[b]{2}{*}{ Sulfur } & \\
\hline & & $\begin{array}{l}\text { Volatile } \\
\text { Matter }\end{array}$ & Ash & $\begin{array}{l}\text { Fixed } \\
\text { Carbon }\end{array}$ & & & & & & \\
\hline $\begin{array}{l}\text { Raw } \\
\text { Biomass }\end{array}$ & 4.64 & 85.25 & 5.52 & 9.23 & 47.47 & 7.18 & 0.55 & 44.79 & 0.0 & 18.34 \\
\hline $\begin{array}{l}\text { Torrefied } \\
\text { Biomass } \\
\text { (250 C, } 1 \\
\text { hours) }\end{array}$ & 2.49 & 81.35 & 6.52 & 12.13 & 51.73 & 6.33 & 0.55 & 41.38 & 0.0 & 20.33 \\
\hline
\end{tabular}

\section{Kinetics Studies}

The kinetics of gasification of raw and torrefied biomass in steam is studied in a QWM reactor (Figure 1) that consists of a stainless steel reactor $50 \mathrm{~mm}$ in diameter encircled by an electric heater. A temperature controller controls temperature inside the reactor. A precision balance sits on the top of the reactor to facilitate the continuous measurement of mass of the substance being examined. A wire basket, whose one end is connected to the balance, holds the sample inside the reactor. The flow rate of gas is continuously measured with an electronic flow meter. Steam flow rate is calibrated against the valve opening and is set at desired point throughout the experiment.

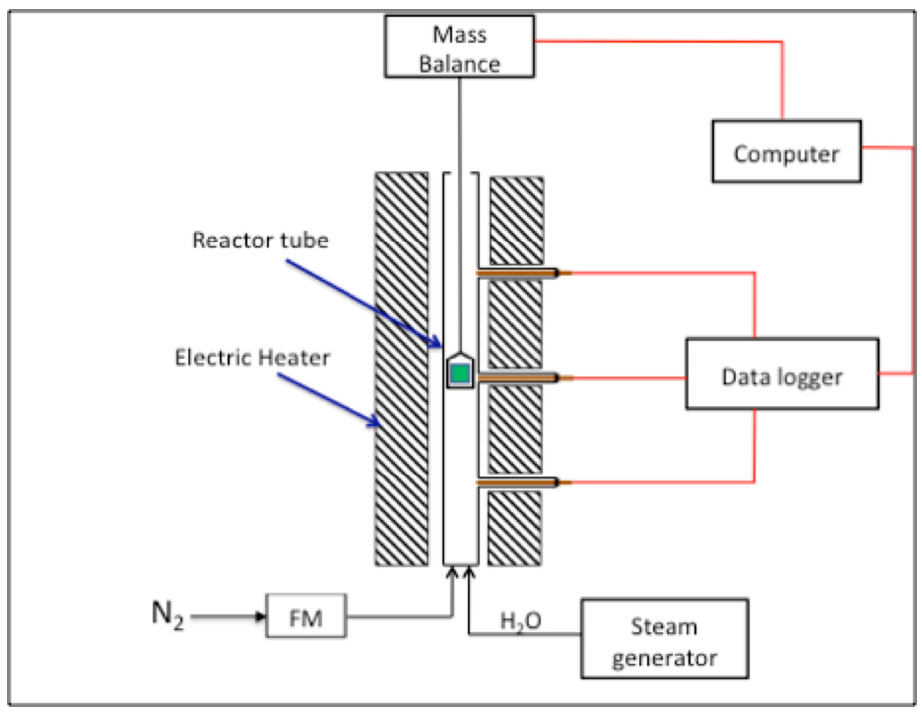

Figure 1: Schematic of $Q W M$ reactor

A cylindrical piece of raw poplar $25 \mathrm{~mm}$ in diameter and $75 \mathrm{~mm}$ long is taken to produce a sample of torrefied biomass. At first, the QWM reactor is heated to the desired torrefaction temperature and the raw biomass is placed in the bucket and dropped inside the reactor flushed with nitrogen. The core temperature of biomass and mass loss is continuously measured, as biomass gets heated and torrefied. The biomass is placed inside QWM for 1.0 hour and is taken out and stored in desiccator. For kinetics studies, one sample of raw biomass and 2 samples of torrefied biomass (torrefied at $250^{\circ} \mathrm{C}$ and $300^{\circ} \mathrm{C}$ for 1 hour) are gasified at five different temperatures: $750^{\circ} \mathrm{C}, 800^{\circ} \mathrm{C}, 850^{\circ} \mathrm{C}, 900^{\circ} \mathrm{C}$, and $950^{\circ} \mathrm{C}$. 
Before gasification samples of both raw and torrefied biomass are devolatilized to produce char under identical conditions. For devolatilization, the reactor is heated to $800^{\circ} \mathrm{C}$ and then the biomass sample i.e. raw and torrefied biomass is dropped into the reactor. Nitrogen is supplied as a gaseous medium to drive off the volatiles while providing an inert environment to suppress the occurrence of any other reactions. The mass loss of the sample is continuously measured, and as the mass becomes constant, the sample is taken out and cooled in a desiccator. The cooled sample is then ground to $300-450$ microns size for gasification tests.

$$
r=\frac{d X}{d t}=k(1-X)
$$

For gasification, the QWM reactor is first preheated to the desired gasification temperature and then the char samples obtained from the above devolatilization tests are placed in the bucket and lowered inside the reactor. The sample is gasified for 1.0 hour in the presence of the steam supplied from the bottom of the reactor. Mass loss during gasification is continuously measured and is used to calculate the char conversion rate. To conduct kinetic studies under isothermal condition, the following rate equation is used (Bhagavatula 2014).

Where $\mathrm{k}\left(\mathrm{min}^{-1}\right)$ is the rate constant which can be defined in the Arrhenius form as:

$$
k=A e^{\left(\frac{-E_{A}}{R T}\right)}
$$

Where, activation energy, $\mathrm{E}_{\mathrm{A}}(\mathrm{kJ} / \mathrm{mol})$ is the minimum energy needed for the reaction to occur, A $(1 / \mathrm{min})$ is frequency factor, $\mathrm{T}$ is the absolute temperature $(\mathrm{K})$ and Universal gas constant, $\mathrm{R}=8.3144 \mathrm{~J} / \mathrm{mol} / \mathrm{K}$.

\section{Mass Balance}

The complete mass balance during gasification to measure the amount of char conversion, gas and tar yield is carried out for raw biomass and biomass torrefied at $250^{\circ} \mathrm{C}$ and $300^{\circ} \mathrm{C}$. However, the result for the complete mass balance of only $250^{\circ} \mathrm{C}$ sample is presented here while information on tar yield is provided for both torrefied biomass cases. For these experiments, the QWM reactor is disconnected with balance and sealed with the cap at the top. The char sample is kept in the basket connected to the cap at the top of the reactor. During gasification, the product gas generated is first moved to condenser and the cleaned gas is then collected in a gasbag. The condensed liquid is evaporated to remove the moisture and the mass is measured for gravimetric tar. The product gas is analysed in a Gas Chromatograph. The solid char product is weighted and examined for change in morphology and surface area using Scanning Electron Microscope (SEM) and Brunauer-Emmett-Teller (BET) analysis respectively. The single-point BET surface area of raw poplar wood, torrefied poplar wood and their char powders is measured with a Micromeritics Flowsorb II 2300 surface area analyzer equipped with a thermal conductivity detector.

\section{Gasification Studies in Bubbling Fluidized Bed Gasifier}

For the continuous gasification in a bubbling fluidized bed gasifier, the poplar wood is cut into cylindrical pieces of size $38 \mathrm{~mm}$ diameter and $10 \mathrm{~mm}$ thick, and then chipped into pieces of average sizes of $10 \mathrm{~mm} \times 10 \mathrm{~mm} \times 4 \mathrm{~mm}$ (Figure 2). For the production of torrefied sample, the small cylindrical piece $(38 \mathrm{~mm}$ diameter and $10 \mathrm{~mm}$ thick) of raw poplar is torrefied at $250^{\circ} \mathrm{C}$ and $275^{\circ} \mathrm{C}$ for 1 hour, and thereafter chipped into the same small size as shown in Figure 2. 


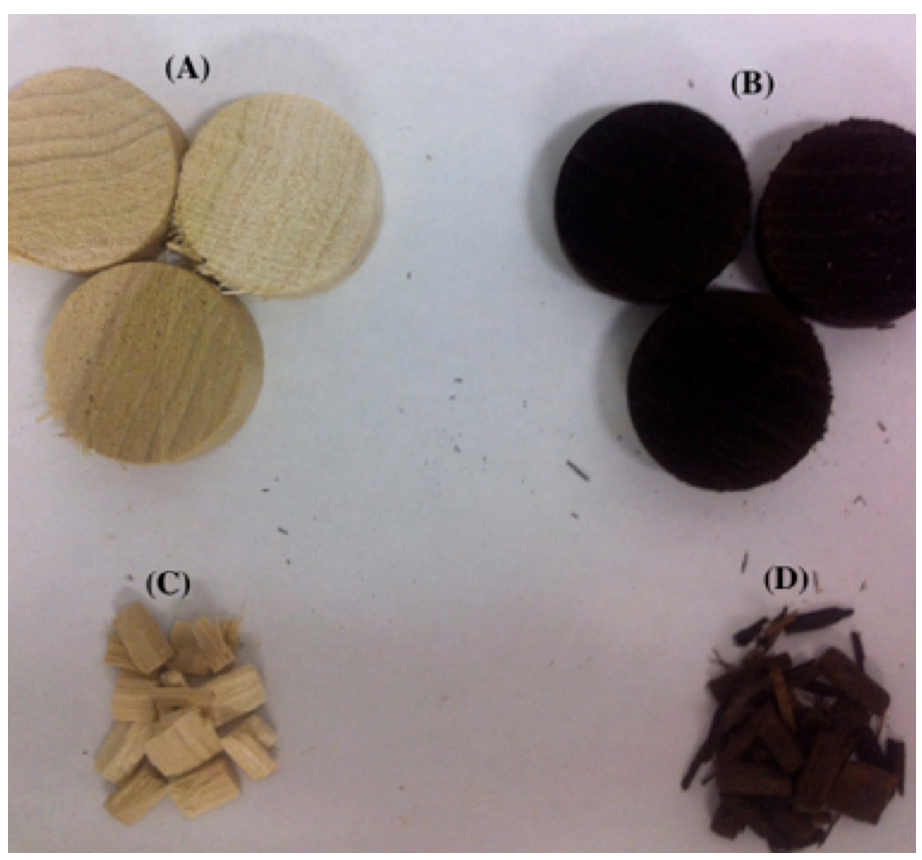

\section{Figure 2: Photographs of biomass for gasifying (A) raw biomass (B) torrefied biomass at $250^{\circ} \mathrm{C}$ (C) raw biomass grinded for gasification (D) torrefied biomass grounded for gasification}

Figure 3 shows the schematic of bubbling bed gasifier used for this study. The gasifier is circular in cross-section with an inside diameter of $152.4 \mathrm{~mm}$ and $1525 \mathrm{~mm}$ height. An electric heater encircles the lower part of the gasifier to heat the gasifier to the desired gasification temperature. Silica sand of average diameter 250-300 micron is used as the bed material. The height to the diameter ratio of the bubbling bed is maintained at 1.0. Saturated steam is generated in an electrical steam generator and is superheated to $250^{\circ} \mathrm{C}$ with the electric wrap heater, before feeding it to the gasifier. Steam plays the dual role of fluidizing agent and gasifying medium. The raw or the torrefied biomass is fed through the screw feeder into the gasifier reactor (Figure 3). The gas produced during gasification leaves from the top of the reactor and passes through a cyclone. The dust particles are separated in the cyclone and then the gas enters into the condenser.
In the condenser, excess moisture and tar component are separated. Finally, the sample of clean gas is collected in one litre Tedlar gasbag from the gas sampling point located at the exit of the condenser. The gas sample is collected at 5 minutes time intervals for 30 minutes. The dry and clean gas is analysed on a SRI 8610C Gas Chromatograph with helium as a carrier gas. The rest of the gases are burnt and passed through a bag house to the atmosphere. A number of thermocouples along the height of the gasifier continuously measure the temperature inside the reactor.

Gasification is carried out at four different temperatures: $700^{\circ} \mathrm{C}, 750^{\circ} \mathrm{C}, 800^{\circ} \mathrm{C}$, and $850^{\circ} \mathrm{C}$. The fuel and steam feed rate is 3 $\mathrm{kg} / \mathrm{h}$ and $1.8 \mathrm{~kg} / \mathrm{h}$ respectively with $\mathrm{S} / \mathrm{B}$ ratio of 0.6 . With this steam flow rate, fluidization velocity of $0.18 \mathrm{~m} / \mathrm{s}$ is obtained to maintain the bed in a bubbling condition. 


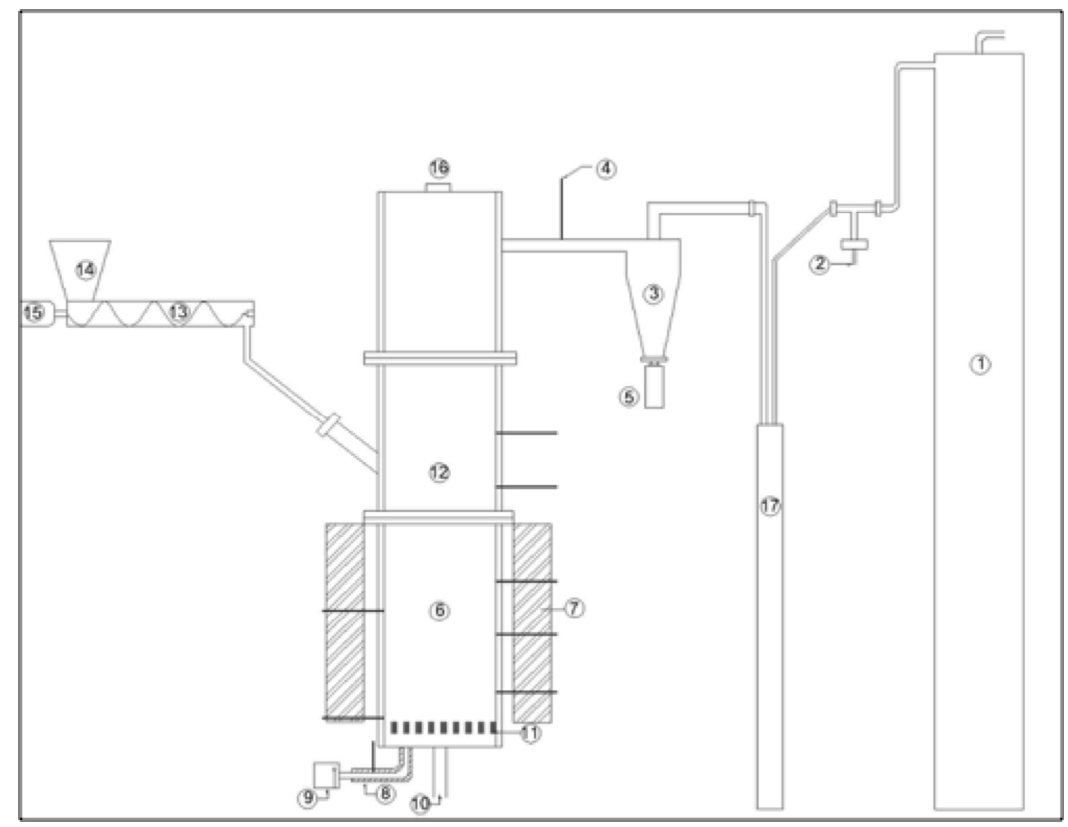

Figure 3: Schematic diagram of lab scale bubbling fluidized bed gasifier

1: bag house, 2: gas sampling point, 3 : cyclone, 4: thermocouple, 5: ash collector, 6: fluidized bed, 7: heater, 8: tape heater, 9: steam generator, 10: drain, 11: distributor plate, 12: freeboard, 13: screw feeder, 14: biomass hopper, 15: motor, 16: view point, 17: cooling tank.

\section{Results and Discussion}

\section{Product Yield}

Table 2 shows the mass yield of char, volatiles and tar obtained during torrefaction, devolatilization and gasification in terms of per unit of raw biomass weight. It is apparent that char yield after devolatilization is on average $43 \%$ higher for torrefied biomass than that for raw biomass, whereas tar yield is lower for torrefied biomass. The product gas yield during gasification is higher for raw biomass char than that for torrefied biomass. Average value of char conversion is $82.07 \%$ for raw biomass compared to $47.21 \%$ for torrefied biomass.

The average value of tar yield is $79 \%$ lower in case of torrefied biomass char as compared to raw biomass char. 
Table 2: Char, volatile and tar yield during torrefaction, devolatilization and gasification

\begin{tabular}{|c|c|c|c|c|c|c|c|c|c|c|}
\hline \multirow[b]{2}{*}{ Sample } & \multirow[t]{2}{*}{$\begin{array}{l}\text { Initial } \\
\text { Mass }\end{array}$} & \multicolumn{3}{|c|}{$\begin{array}{l}\text { Torrefaction } \\
\left(250^{\circ} \mathrm{C} / 1 \mathrm{hr}, \mathrm{N}_{2}\right) \\
\end{array}$} & \multicolumn{3}{|c|}{$\begin{array}{l}\text { Devolatilization } \\
\left(800^{\circ} \mathrm{C} / 1 \mathrm{hr}, \mathrm{N}_{2}\right)\end{array}$} & \multicolumn{3}{|c|}{$\begin{array}{l}\text { Gasification } \\
\left(8^{\circ} \mathrm{C} / 15 \mathrm{~min}, \text { Steam }\right)\end{array}$} \\
\hline & & $\begin{array}{l}\text { Solid } \\
\text { Biomass } \\
(\mathrm{g} / \mathrm{g})\end{array}$ & $\begin{array}{l}\text { Volatile } \\
\text { (g/g) }\end{array}$ & $\begin{array}{l}\text { Tar } \\
(\mathrm{g} / \mathrm{g})\end{array}$ & $\begin{array}{l}\text { Char } \\
\text { (g/g) }\end{array}$ & $\begin{array}{l}\text { Volatile } \\
\text { (g/g) }\end{array}$ & $\begin{array}{l}\text { Tar } \\
(\mathrm{g} / \mathrm{g})\end{array}$ & $\begin{array}{l}\text { Char } \\
\text { (g/g) }\end{array}$ & $\begin{array}{l}\text { Gas } \\
(\mathrm{g} / \mathrm{g})\end{array}$ & $\begin{array}{l}\text { Tar } \\
\text { (g/g) }\end{array}$ \\
\hline Raw1 & 5.7203 & & & & 0.081 & 0.909 & 0.010 & 0.010 & 0.162 & 0.0015 \\
\hline Raw 2 & 5.6949 & & & & 0.102 & 0.889 & 0.009 & 0.020 & 0.133 & 0.0016 \\
\hline Raw 3 & 5.7218 & & & & 0.107 & 0.882 & 0.011 & 0.023 & 0.176 & 0.0013 \\
\hline Torrefied 1 & 5.72 & 0.7596 & 0.2391 & 0.0013 & 0.130 & 0.625 & 0.005 & 0.067 & 0.119 & 0.0002 \\
\hline Torrefied 2 & 5.7046 & 0.7321 & 0.2667 & 0.0012 & 0.155 & 0.573 & 0.004 & 0.078 & 0.115 & 0.0005 \\
\hline Torrefied 3 & 5.7152 & 0.7499 & 0.2488 & 0.0013 & 0.131 & 0.614 & 0.005 & 0.074 & 0.121 & 0.0002 \\
\hline
\end{tabular}

\section{SEM Analysis}

Figure 4 shows the SEM micrographs of raw and torrefied samples of poplar wood. Here, it can be seen that the raw biomass is more fibrous in nature. But after it is torrefied, the fibrous structure of the raw sample is broken down with distinct increase in pores. These pores are created by the volatiles as they escape from the biomass interior during torrefaction. Chen et al. (2011) suggested that the volume of pores with diameter 20-100 nm increased after torrefaction. Luo (2011) also found that the number of openings on the surface of the biomass has increased after the torrefaction. These additional pores might serve as additional sites for the char reaction.
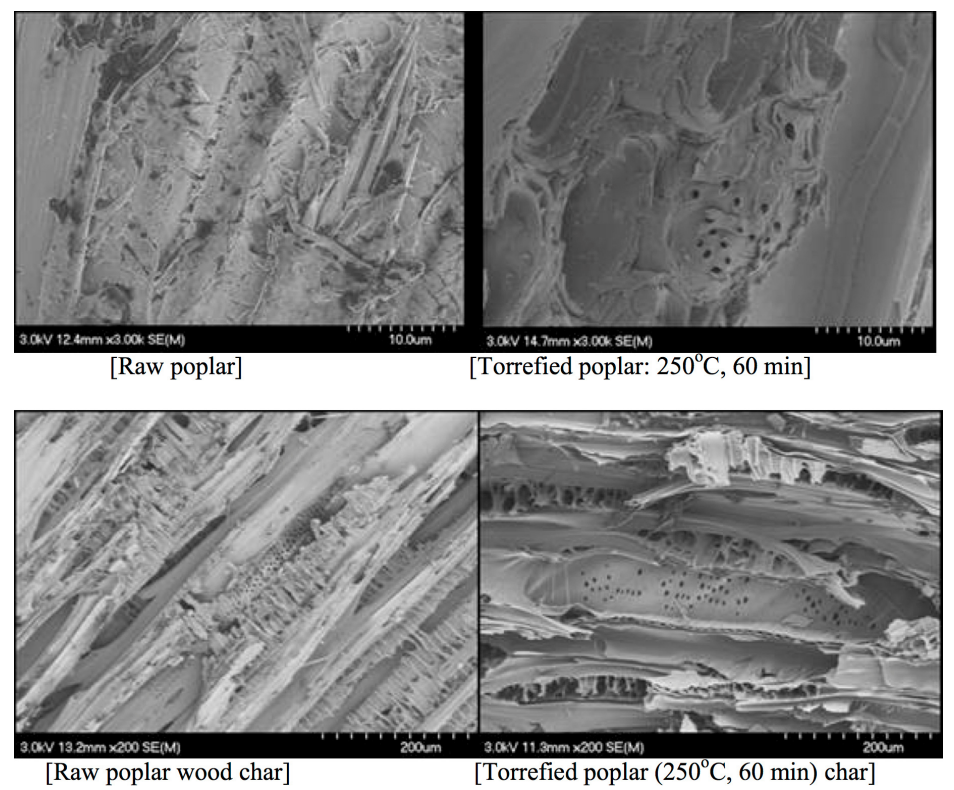

Figure 4: SEM micrographs of raw and torrefied poplar

Table 3 shows results from BET analysis of the raw, torrefied (at $250^{\circ} \mathrm{C}$ ), raw char and torrefied char. There is significant increase in the surface area of both raw and torrefied biomass as they undergo devolatilization but the overall surface area 
is higher for torrefied biomass. Vincent et al. (2014) also reported similar observation for pyrolyzed flax straw char and torrefied flax straw char. This suggests that torrefied biomass char should have higher reactivity during gasification compared to raw char. However, the results of the kinetic study discussed above shows an opposite trend. It showed that during torrefaction, there is the formation of less reactive secondary char. So, in spite of having a larger surface area, torrefied char has lower gasification rate.

Table 3: Surface area of biomass and torrefied samples

\begin{tabular}{|c|c|c|c|c|}
\hline \multirow{2}{*}{ Sample No. } & \multicolumn{4}{|c|}{ Surface Area $\left.\mathbf{( m}^{\mathbf{2}} / \mathbf{g}\right)$} \\
\cline { 2 - 5 } & Raw biomass & Torrefied biomass & Raw char & Torrefied char \\
\hline $\mathbf{1}$ & 0.0098 & 0.42 & 616.7 & 747.0 \\
\hline $\mathbf{2}$ & 0.0098 & 0.36 & 611.3 & 773.9 \\
\hline $\mathbf{3}$ & 0.0098 & 0.36 & 613.3 & 767.2 \\
\hline
\end{tabular}

\section{Kinetics Study}

The Arrhenius plot for the gasification reaction of char produced from raw and torrefied biomass in the presence of steam is shown in Figure 5. It shows that the kinetic rate of gasification of torrefied biomass is lower than that of raw biomass. Dudynski et al. (2015) also found the rate of gasification two times smaller for torrefied pellets. The difference in reactivity could be associated with changes to the biomass structure that takes place during torrefaction. Torrefaction is characterized by a slow heating rate. So, the volatile released from the sample interior finds sufficient time to undergo condensation on the pore walls of char around it. This condensation forms additional char known as secondary char.
For this reason the char yield from torrefied biomass after devolatilization is higher $(43 \%)$ than that from the raw biomass, which confirms the formation of secondary char. This is more prominent in larger size biomass similar to that considered in this study (Dhungana, 2011).

The characteristic of secondary char is different from that of primary char. Fisher et al. (2012) found that secondary char formed during torrefaction has a lower reactivity. So, the gasification of torrefied biomass involves the reaction of less reactive secondary char while that of raw biomass generally involves reactive primary char. Therefore, the overall reactivity of torrefied biomass during gasification is lower than the raw biomass.

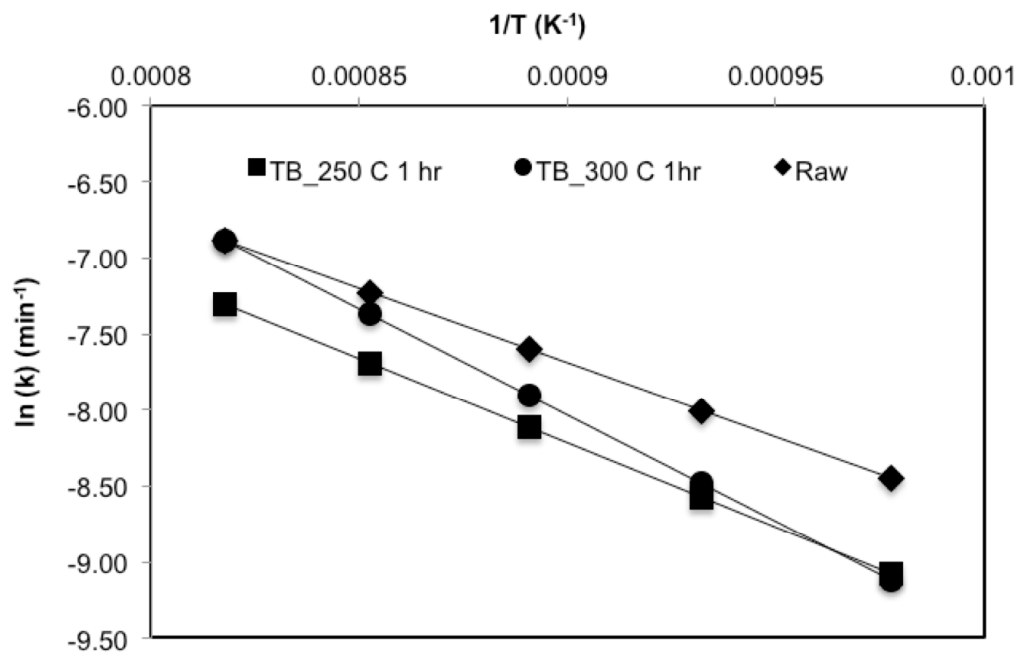

Figure 5: Arrhenius plot for gasification reaction of char obtained from raw and torrefied biomass

Manoj K. Raut, Prabir Basu and Bishnu Acharya (2016), International Journal of Renewable Energy and Biofuels, DOI: 10.5171/2016.823723 


\section{Product Yield During Gasification}

The total gas yield for the torrefied biomass was slightly lower compared to raw biomass (Figure 6). We noted from earlier discussion that the raw biomass char is a little more reactive than torrefied char, as such former gives a higher gas yield then torrefied biomass does. Figure 6 also shows that there is not much difference in the gasification reaction rate between the biomass torrefied at $250^{\circ} \mathrm{C}$ and $300^{\circ} \mathrm{C}$. Thus, when gasified at $800^{\circ} \mathrm{C}$ the gas yield of both torrefied biomass is almost the same.
Figure 6 shows the composition and gas yield of the product gas obtained from the gasification of char of raw and torrefied biomass. The gas sample collected during experiments is analysed for gas components hydrogen $\left(\mathrm{H}_{2}\right)$, carbon monoxide ( $\mathrm{CO})$, carbon dioxide $\left(\mathrm{CO}_{2}\right)$, and methane $\left(\mathrm{CH}_{4}\right)$. It shows higher $\mathrm{H}_{2}$ and $\mathrm{CO}$ for torrefied biomass with lower carbon dioxide concentration. Similar observation is reported by Tapasvi et al. (2015). The concentration of methane in product gas is $27 \%$ lower for torrefied biomass. Reasons for this are explained in details later for continuous gasification in bubbling fluidized bed reactor

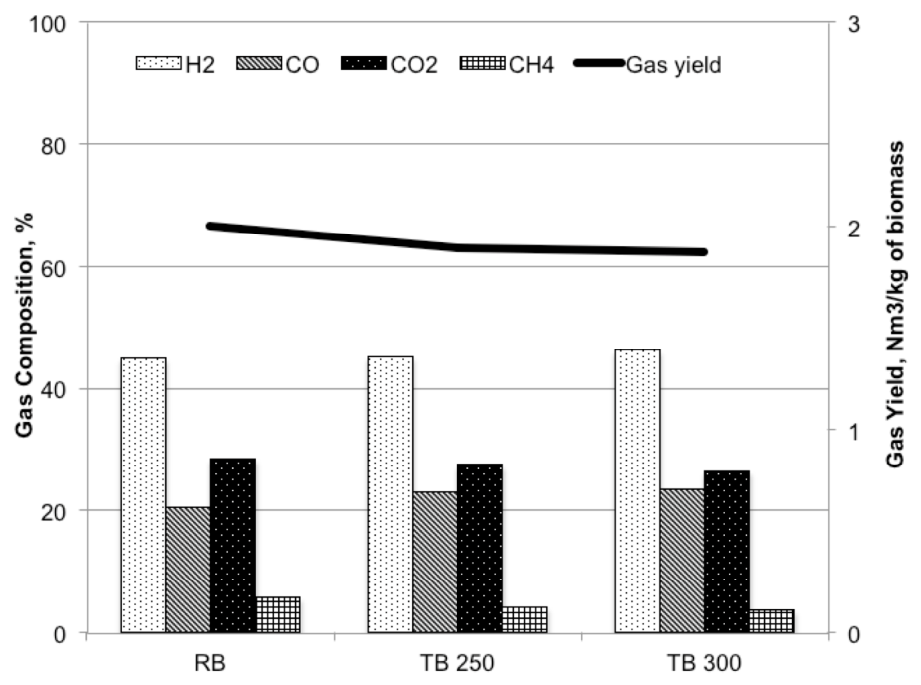

Figure 6: Product gas composition of raw and torrefied biomass char gasified at $800^{\circ} \mathrm{C}$

\section{Tar Yield}

Table 4 shows the total tar yields during the gasification of raw and torrefied biomass (produced at $250^{\circ} \mathrm{C} \& 300^{\circ} \mathrm{C}$ and 1 hour residence time) at $800^{\circ} \mathrm{C}$ in the presence of steam. From Table 4, it is evident that the tar yield for torrefied biomass is lower than that of raw biomass. Sweeney (2012) also found 66\% reduction in the tar yield of gasification for dark roasted torrefied biomass as compared to raw biomass when gasified in a bubbling fluidized bed gasifier.
This reduction can be explained as below. The lignin and the hemicellulose components in a lignocellulose biomass make major contribution to the tar formation (Kiel et al. 2004). During torrefaction, most of the hemicellulose is devolatilized and lignin is partially devolatilized. Thus, when the torrefied product is gasified, less tar remains to be produced. Studies done on the pyrolysis of lignin showed that some decomposition of lignin occurs within the temperature range of $200-400^{\circ} \mathrm{C}$ (Beis et al. 2010). During this

Manoj K. Raut, Prabir Basu and Bishnu Acharya (2016), International Journal of Renewable Energy and Biofuels, DOI: 10.5171/2016.823723 
decomposition, aromatic hydrocarbons, phenolic, hydroxyphenolics and guaiacyl/syringyl-type compounds, which mostly have phenolic-OH groups, are formed. These constitute the bulk of the tar (Brebu and Vasile, 2009). During torrefaction, which occurs between 200$300^{\circ} \mathrm{C}$, some of these tar components are released thereby reducing the tar produced during the subsequent devolatilization of the torrefied biomass. Also, as the heating rate is relatively low during torrefaction, the rate of volatilization of lignin fragments is not sufficiently high to avoid the formation of the secondary char (Brebu and Vasile, 2009). The secondary char is therefore formed, and since it is more stable during devolatilization and gasification, the tar yield is also less for torrefied biomass compared to that for raw biomass.

Table 4: Total tar yield from gasification of raw and torrefied biomass chars at $800^{\circ} \mathrm{C}$

\begin{tabular}{|c|c|c|c|}
\hline & \multirow{2}{*}{ Raw Biomass } & \multicolumn{2}{|c|}{ Torrefied Biomass Char } \\
\hline & & $250^{\circ} \mathrm{C} / 1 \mathrm{hr}$ & $300^{\circ} \mathrm{C} / 1 \mathrm{hr}$ \\
\hline Tar (mg/g of raw biomass) & 10.12 & 6.39 & 3.08 \\
\hline
\end{tabular}

\section{Gasification in Bubbling Bed}

This section analyses the results of the continuous gasification of raw biomass and torrefied biomass in the bubbling fluidized bed. The effect of temperature on the gas yield, the composition and heating value of the product gas for different biomass sample are shown in Table 5.

\section{Effect of gasification temperature on gas composition}

As shown in Table 5, the percentage of hydrogen and carbon monoxide increases with the increase in gasification temperature. As the temperature increases, it enhances the steam char reaction $\mathrm{C}+$ $\mathrm{H}_{2} \mathrm{O}=\mathrm{CO}+\mathrm{H}_{2}$ ) forming higher hydrogen and carbon monoxide (Gao et al. 2008; Rapagna and Latif, 1997). When compared to raw biomass, torrefied biomass gasification shows higher concentration of hydrogen and lower carbon monoxide in product gas. Sweeney (2012) also found a similar trend for the raw and torrefied biomass. During torrefaction, noncondensable volatiles $\mathrm{CO}$ and $\mathrm{CO}_{2}$ escape from the biomass. So, the torrefied biomass is left with char with lower $0 / C$ ratio, and when it is gasified, the torrefied biomass gives lower $\mathrm{CO}$ and $\mathrm{CO}_{2}$ compared to that with raw biomass. For this reason, CO concentration is lower for torrefied biomass. This also results in higher $\mathrm{H}_{2} / \mathrm{CO}$ ratio in the product gas for torrefied biomass compared to raw biomass. Initially, when the gasification temperature is increased from 700 to $750^{\circ} \mathrm{C}$, there is an increase in $\mathrm{H}_{2} / \mathrm{CO}$ ratio and it becomes nearly constant at higher temperature. This is because the temperature range of 700$750^{\circ} \mathrm{C}$ still favours the water gas shift reaction $\left(\mathrm{CO}+\mathrm{H}_{2} \mathrm{O}=\mathrm{CO}_{2}+\mathrm{H}_{2}\right)$ by which some $\mathrm{CO}$ is converted into hydrogen. Thus, the $\mathrm{H}_{2} / \mathrm{CO}$ ratio increases in this temperature range. But at higher temperature, the water gas shift reaction ceases resulting in a more constant $\mathrm{H}_{2} / \mathrm{CO}$ ratio. The other component of product gas i.e. $\mathrm{CO}_{2}$ and $\mathrm{CH}_{4}$ decreases with the increase in temperature. The higher steam gasification temperature favours reformation of the volatiles, resulting in lower $\mathrm{CH}_{4}$ in the product gas. During torrefaction, as some of the volatile and $\mathrm{CO}_{2}$ are released, the concentrations of $\mathrm{CO}_{2}$ and $\mathrm{CH}_{4}$ are lower in the product gas for torrefied biomass as compared to those for raw biomass. 
Table 5: Results of gasification study of raw and torrefied biomass In a bubbling bed gasifier

\begin{tabular}{|c|c|c|c|c|}
\hline & \multicolumn{4}{|c|}{ Gasification temperature $\left({ }^{\circ} \mathrm{C}\right)$} \\
\hline & 700 & 750 & 800 & 850 \\
\hline $\mathrm{H}_{2 \_} \mathrm{RB}$ & 37.48 & 38.88 & 40.86 & 43.91 \\
\hline CO_RB & 25.68 & 26.07 & 27.16 & 29.03 \\
\hline $\mathrm{CO}_{2} \_\mathrm{RB}$ & 20.16 & 18.53 & 17.19 & 16.71 \\
\hline $\mathrm{CH}_{4 \_} \mathrm{RB}$ & 11.86 & 11 & 9.85 & 8.13 \\
\hline Gas yield_RB & 0.95 & 1.08 & 1.69 & 2.44 \\
\hline Heating Value of Gas_RB & 12.78 & 12.66 & 12.6 & 12.54 \\
\hline $\mathrm{H}_{2} / \mathrm{CO}$ Ratio_RB & 1.46 & 1.49 & 1.50 & 1.51 \\
\hline $\mathrm{H}_{2} \_\mathrm{TB} \_250$ & 40.67 & 43.18 & 44.45 & 47.91 \\
\hline CO_TB_250 & 23.87 & 24.37 & 25.72 & 26.91 \\
\hline $\mathrm{CO}_{2} \_\mathrm{TB} \_250$ & 18.3 & 16.92 & 15.51 & 15.1 \\
\hline $\mathrm{CH}_{4 \_} \mathrm{TB} \_250$ & 11.05 & 9.92 & 8.16 & 6.41 \\
\hline Gas yield_TB_250 & 0.63 & 0.91 & 1.36 & 1.88 \\
\hline Heating Value of Gas_TB_250 & 12.63 & 12.56 & 12.21 & 12.09 \\
\hline $\mathrm{H}_{2} / \mathrm{CO}$ Ratio_TB_250 & 1.70 & 1.77 & 1.73 & 1.78 \\
\hline $\mathrm{H}_{2 \_} \mathrm{TB} \_275$ & 42.96 & 45.72 & 47.81 & 49.93 \\
\hline CO_TB_275 & 22.9 & 22.97 & 24.12 & 25.21 \\
\hline $\mathrm{CO}_{2 \_} \mathrm{TB} \_275$ & 16.88 & 15.64 & 14.26 & 13.79 \\
\hline $\mathrm{CH}_{4 \_} \mathrm{TB} \_275$ & 10.18 & 9.2 & 7.62 & 5.82 \\
\hline Gas yield_TB_275 & 0.49 & 0.83 & 1.11 & 1.54 \\
\hline Heating Value of Gas_TB_275 & 12.54 & 12.42 & 12.21 & 11.9 \\
\hline $\mathrm{H}_{2} / \mathrm{CO}$ Ratio_TB_275 & 1.88 & 1.99 & 1.98 & 1.98 \\
\hline
\end{tabular}

\section{Effect of gasification temperature on gas yield}

Table 5 also shows the gas yield obtained from the gasification of raw and torrefied biomass at different temperatures. It is found that with the increase in gasification temperature, gas yield increases. Higher temperature favours the steam char reaction resulting in higher gas yield. Also, the tar released during gasification is reformed at higher temperature in the presence of steam, resulting in an overall increase in gas yield with an increase in gasification temperature. The yield for raw biomass is consistently higher than that from torrefied biomass. During torrefaction, some of the gas is released, so when gasified results in lower gas yield. Additionally, the low char reactivity of torrefied biomass also resulted in a lower gas yield during gasification. This observation is consistent with what was observed in batch experiments in the QWM reactor.

\section{Effect of gasification temperature on gas heating value}

Table 5 compares the heating value of the product gas obtained from the gasification of raw biomass and torrefied biomass at different gasification temperatures. The heating value of product gas from the gasification of raw biomass is higher than that for the torrefied biomass. This 
difference is even more significant at higher gasification temperature. The energy loss during the torrefaction process resulted in lower heating value of the product gas obtained from gasification of torrefied biomass. Also as discussed in the tar section, more tar is released from raw biomass char gasification as compared to torrefied biomass. Some of this tar component undergoes reformation adding more energy value to the product gas. As the tar reformation is significant at higher temperature, the heating value of the product gas is higher for raw biomass at higher temperature compared to torrefied biomass.

The present study is based on a conventional dry woody biomass, (poplar). The difference in gasification output could be minimal if other types of biomass such as bio-waste, MSW, agricultural wastes are to be torrefied and used for gasification. The handling of such heterogeneous and high moisture content biomass often limits the use of such opportunity fuel for gasification. This limitation can be eliminated by torrefaction pre-treatment, which could make it more favourable for gasification.

\section{Conclusion}

The gasification of torrefied biomass is certainly an attractive alternative to raw biomass gasification, as it helps to reduce the tar generation and increases the quality of gas. Studies showed tar reduction by $79 \%$ that can reduce the cost and effort for downstream gas cleaning. Liquid biofuel production requires $\mathrm{H}_{2} / \mathrm{CO}$ ratio to be 2 and the present study showed that the gasification of biomass torrefied at $275^{\circ} \mathrm{C}$ produces a gas with $\mathrm{H}_{2} / \mathrm{CO}$ ratio close to 2 making it suitable for liquid biofuel production. However, it suffers from reduced reactivity and lower gas yield. Improved in properties of raw biomass through torrefaction could well compensate this limitation of torrefied biomass. Further studies have to be done with other kinds of fuels like agricultural waste which may have higher advantages of torrefaction for gasification as compared to woody biomass.

\section{Acknowledgements}

The authors would like to acknowledge the Natural Sciences and Engineering Research Council of Canada, and Greenfield Research Incorporated, Canada for the financial and technical supports to carry out the above studies.

\section{Nomenclature}

\begin{tabular}{|c|c|}
\hline$A$ & Frequency factor $\left[\mathrm{min}^{-1}\right]$ \\
\hline C & Carbon \\
\hline $\mathrm{CO}$ & Carbon monoxide \\
\hline $\mathrm{CO}_{2}$ & Carbon dioxide \\
\hline $\mathrm{CH}_{4}$ & Methane \\
\hline$E_{A}$ & Activation \\
\hline \multicolumn{2}{|l|}{ [kJ/mol] } \\
\hline $\mathrm{H}_{2}$ & Hydrogen \\
\hline $\mathrm{H}_{2} \mathrm{O}$ & Steam/moisture \\
\hline$k$ & Rate Constant [min-1] \\
\hline$L H V$ & Low heating value \\
\hline$M S W$ & Municipal solid waste \\
\hline$N$ & Normal atmospheric \\
\hline condition & \\
\hline$R$ & Universal gas \\
\hline$[\mathrm{J} / \mathrm{mol} / \mathrm{K}]$ & \\
\hline$T$ & Temperature [Kelvin] \\
\hline TB & Torrefied Biomass \\
\hline$X$ & Char Conversion [-] \\
\hline$r$ & Reaction rate [min-1] \\
\hline RB & Raw Biomass \\
\hline
\end{tabular}

\section{References}

1. Basu, P., 2013. Biomass gasification, pyrolysis and torrefaction: Practical design and theory, Second ed. Academic press, an imprint of Elsevier, London NW1 7BY, UK.

2. Bergman, P.C.A., Boersma, A. R., Kiel, J. H. A., Prins, M. J., Ptasinski, K. J., and Janssen, F. J. J. G., 2004. Torrefaction for entrained flow gasification of biomass. The 2nd World Conference and Technology Exhibition on Biomass for Energy, Industry and Climate Protection, Rome, Italy.

3. Beis, H. S., Mukkamala, S., Hill, N., Joseph, J., Baker, C., Jensen, B. and Stemmler, E. A., 2010. Fast pyrolysis of lignins. Bio Resources 5, 1408-1424. 
4. Brebu, M. and Vasile, C., 2010. Thermal degradation of lignin - a review. Cellulose chem. Technol., 44 (9), 353-363.

5. Couhert, C., Salvador, S., and Commangre, J. M., 2009. Impact of torrefaction on syngas production from wood. Fuel, 88, 2286-2290.

6. Chen, Q., Zhou, J. S., Liu, B. J., Mei, Q. F., and Luo, Z. Y., 2011. Influence of torrefaction pretreatment on biomass gasification technology. Chinese Sci Bulletin, 56, 1449-1456.

7. Devi, L., Ptasinski, K. J., and Janssen, F. J. J. G., 2003. A review of the primary measures for tar elimination in biomass gasification processes. Biomass and Bioenergy, 24, 125 - 140.

8. Dhungana, A., 2011. Torrefaction of biomass. M. A. Sc. Thesis, Dalhousie University, Halifax, Nova Scotia.

9. Dutta, A., and Acharya, B. (2011) Chapter 16: Production of bio-syngas and bio-hydrogen via gasification. Handbook of Biofuels Production- Processes and Technologies, Woodhead Publishing Limited, 420-459.

10.Dudynski, M., Dyk, J.C.V., Kwiatkowski, K., and Sosnowska, M., 2015. Biomass gasification: Influence of torrefaction on syngas production and tar formation.

11.Fisher, E. M., Dupont, C., Darvell, L. I., Commandré, J.-M., Saddawi, A., Jones, J. M., Grateau, M., Nocquet, T. and Salvador, S., 2012. Combustion and gasification characteristics of chars from raw and torrefied biomass. Bioresource Technology, $119,157-165$

12.Gao, N., Li, A., Quan, C., and Gao, F., 2008. Hydrogen-rich gas production from biomass steam gasification in an updraft fixed-bed gasifier combined with a porous ceramic reformer. International Journal of Hydrogen Energy, 33, 5430-5438.

13.Kiel, J.H.A., Van Paasen, S.V.B., Neeft, J.P.A., Devi, L., Ptasinski, K.J., Janssen, F.J.J.G., Meijer, R., Berends, R.H., Temmink, H.M.G., Brem, G., Padban, N. and Bramer, E.A., 2004. Primary Measures to Reduce Tar
Formation in Fluidized-Bed Biomass Gasifiers. ECN-C-04-014. The Netherlands, Energy Research Center of the Netherlands (ECN).

14.Luo, X., 2011. Swedish University of Agricultural Sciences, Dept. of Energy and Technology, ISSN 1654-9392.

15.Meijden, C. M. V., Drift, A.V., and Vreugdenhil, B.J. (2012). Benefits of Allothermal biomass gasification for cofiring. $2^{\text {nd }}$ workshop on cofiring biomass with coal, Copenhagen, Denmark.

16.Rapagna, S. and Latif, A., 1997. Steam gasification of almond shells in a fluidised bed reactor: the influence of temperature and particle size on product yield and distribution. Biomass and Bioenergy 12, 281-288.

17.Sweeney, D. J., 2012. Performance of a pilot scale, steam blown, pressurized fluidized bed biomass gasifier. Ph.D. Thesis, Department of Mechanical Engineering, The University Of Utah, USA.

18.Prins, M. J., Ptasinski, K. J., and Janssen, F. J. J. G., 2006. More efficient biomass gasification via torrefaction. Energy, 31, 3458-3470.

19.Svoboda, K., Pohorel, M., Hartman, M., and Martinec, J., 2009. Pretreatment and feeding of biomass for pressurized entrained flow gasification. Fuel Processing Technology, 90, 629-635.

20.Slopiecka, K., Bartocci, P., and Fantozzi, F., 2012. Thermogravimetric analysis and kinetic study of poplar wood pyrolysis. Applied Energy, 97, 491-497.

21.Tapasvi, D., Kempegowda, R.S., Tran, K.Q., Skreiberg, Q., Gronli, M., 2015. A simulation study on the torrefied biomass gasification. Energy Conversion and Management, 90: 446-457.

22.Vincent, S. S., Mahinpey, N., \& Aqsha, A., 2014. Mass transfer studies during $\mathrm{CO}_{2}$ gasification of torrefied and pyrolyzed char. Energy, 67: 319-327. 